\title{
An alternative pathway for plant in vitro regeneration of chinaberry -tree Melia azedarach $L$. derived from the induction of somatic embryogenesis
}

\author{
Sandra Sharry* \\ Centro Experimental de Propagación Vegetativa (C.E.Pro.Ve) \\ Facultad de Ciencias Agrarias y Forestales \\ Universidad Nacional de La Plata \\ C.C 31, (1900), La Plata \\ Buenos Aires, Argentina \\ Tel: 542214236616 \\ Fax: 542214252346 \\ E-mail: ceprove@ceres.agro.unlp.edu.ar \\ José Luis Cabrera Ponce \\ Unidad Irapuato \\ Departamento de Genética \\ Centro de Estudios Avanzados \\ Instituto Politécnico Nacional (CINVESTAV-IPN) \\ Tel: 524626239606 \\ Fax: 524626245846 \\ E-mail: jlcabrera@ira.cinvestav.mx \\ Luis Herrera Estrella \\ Centro de Estudios Avanzados del IPN (CINVESTAV-IPN) \\ Unidad Irapuato \\ Departamento de Genética \\ Tel: 524626239606 \\ Fax: 524626245846 \\ E-mail: 1herrera@ira.cinvestav.mx

\section{Rosa María Rangel Cano} \\ Centro de EstudiosAvanzados del IPN (CINVESTAV-IPN) \\ Unidad Irapuato \\ Departamento de Genética \\ Tel: 524626239606 \\ Fax: 524626245846 \\ E-mail: rrangel@ira.cinvestav.mx

\section{Silvia Lede} \\ Centro Experimental de Propagación Vegetativa (C.E.Pro.Ve) \\ Facultad de Ciencias Agrarias y Forestales \\ Universidad Nacional de La Plata \\ C.C 31, (1900), La Plata \\ Buenos Aires, Argentina \\ Tel: 542214236616 \\ Fax: 542214252346 \\ E-mail: ceprove@ceres.agro.unlp.edu.ar \\ Walter Abedini \\ Centro Experimental de Propagación Vegetativa (C.E.Pro.Ve) \\ Facultad de Ciencias Agrarias y Forestales \\ Universidad Nacional de La Plata \\ C.C 31, (1900), La Plata \\ Buenos Aires, Argentina \\ Tel: 542214236616 \\ Fax: 542214252346 \\ E-mail: ceprove@ceres.agro.unlp.edu.ar
}

Financial support: Comisión de Investigaciones Científicas de la Provincia de Buenos Aires (CICPBA).

Keywords: callus induction, clonal forestry, embryos conversion, micropropagation, persian lilac, somatic embryos.

*Corresponding author 


\author{
Abbreviations: 2,4-D: 2, 4 Diclorophenoxyacetic acid \\ Ade: Adenine \\ $\mathrm{AG}_{3}$ : Giberellic acid \\ BAP: $\mathrm{N}^{6}$ - Benzylaminopurine \\ HC: Hydrolized Casein \\ IAA: Indole-3-acetic acid \\ IBA: Indole-3- butyric acid \\ MS: Murashige and Skoog's medium \\ NAA: 1-Naphtaleneacetic acid \\ $\mathrm{NaOCl}$ : sodium chloride \\ PGR: plant growth regulator \\ Put: Putrescine \\ SE: Somatic embryogenesis
}

A highly efficient somatic embryogenesis system and subsequent plant regeneration of chinaberry (Melia azedarach $L_{\text {.) }}$ was developed. Plants were regenerated from indirect somatic embryogenesis induction. Novel features of this improved protocol, include: a) Embryogenic callus induction with no addition of 2, 4-D in the culture media; b) Somatic embryos differentiation was achieved by using high concentration of cytokinins (BAP $10 \mathrm{mg} / \mathrm{L}$ ) and adenine; c) $100 \%$ conversion of somatic embryos to plants was practically obtained and $100 \%$ of plants survived under greenhouse conditions; d) Addition of putrescine improved somatic embryos germination. The amount of somatic embryos produced by the pathway of indirect somatic embryogenesis was 447 per gram of fresh weight callus. Regenerated plants were phenotypically normal. The developed protocol established the potential to produce plantlets from cotyledon explants through somatic embryogenesis. It also presents itself as a highly efficient method for mass clonal propagation and conservation of Melia azedarach.

Clonal forestry offers very significant advantages for forest productivity due to the genetic volume gain and quality improvements which can be obtained through selection and mass propagation of elite individuals (clones). In addition, efficiencies in forest management and end product utilization may also be achieved. Somatic embryogenesis (SE) is a new advancement in vegetative propagation technology for plants, which has a major impact on tree breeding and high-value clonal forestry (Park, 2002; Sutton, 2002). SE is a highly efficient method for cloning genetically improved trees and offers the potential for storage and testing of clones as well as production of unlimited numbers of plants. Thus, it is widely believed that embryogenic cultures might eventually be used in commercial-scale production of cloned propagules of forest trees. However, considerably greater production rates and large-scale handling systems are required in order to use SE for mass production of somatic seedlings for operational deployment (Sutton, 2002). Somatic embryos can be used for scale-up in liquid culture (i.e. bioreactors) and for direct delivery to the greenhouse or field as artificial seeds (Merkle et al. 1990). Such features make it likely that cloned propagules produced via somatic embryogenesis will have significantly lower costs per unit than those produced using other micropropagation systems (Merkle, 1995). Furthermore, embryogenic cultures of forest trees have also been shown to make excellent target material for gene transfer via Agrobacterium-Ti plasmid-mediated and biolistic transformation (Tzfira et al. 1998; Merkle and Dean, 2000). Dramatic progress in induction of somatic embryogenesis and production of somatic embryo-derived plantlets of both coniferous and hardwoods has been made in the past decade. The major limitations to the application of somatic embryogenesis for propagation and genetic manipulation of hardwoods are the low multiplication rates and the low number of field-plantable cloned plantlets produced per embryogenic culture. Thus, it is not only useful for somatic embryo-derived plantlet production to be either low or high, because in over half of the cases plantlets are not regenerated at all. There are many other problems besides the low rates of multiplication, such as low or abnormal somatic embryo production frequency, incomplete maturation, low and non-synchronous germination, and low conversion of germinant to plantlets capable of surviving transfer to ex vitro conditions (Merkle, 1995). The establishment of embryogenic cultures that are capable of overcoming these limitations implies the optimization of a number of key technical developments.

Chinaberry or Persian lilac (Melia azedarach L., Meliaceae) is an Asiatic multipurpose tree of worldwide cultivation with economical importance. It withstands cooler climates better than its related tree "neem" (Azidarachta indica A. Juss) and it is a fast-growing species with long lasting wood, used as a component of agroforestry systems with inter cropping annual species (Prassad et al. 1993; Saymaiya and Shukla, 1998). Moreover, Chinaberry is resistant to locust and ants and is a good source of natural compounds with potent insecticide and anitmicrobial action (Wang et al. 1994; Schmidt et al. 1998, Carpinella et al. 1999). Tissue culture of Melia azedarach var. gigantea has been established in order to reach different objectives (Domecq, 1988; Olmos et al. 2002; Vila et al. 2003-2004). Micropropagation of Melia azedarach L. has been previously established by Ahmad et al. (1990), Thakur et al. (1998) and Sharry and Abedini (2001) from an organogenic pathway. However, few reports dealing with somatic embryogenesis have been published (Vila et al. 2003) and most of the results for this 
Table 1. Formulation of culture media.

\begin{tabular}{|c|c|c|c|c|c|}
\hline & $\begin{array}{l}\text { Basal } \\
\text { Medium }\end{array}$ & $\begin{array}{l}\text { Auxin/ } \\
\text { Giberellin }\end{array}$ & Citokynine & $\begin{array}{l}\text { Carbon } \\
\text { source }\end{array}$ & Other additives \\
\hline Callus Induction Medium (CIM) & $\mathrm{MS} / 2$ & $\begin{array}{l}\mathrm{NAA} 3 \mathrm{mg} / \mathrm{L} \\
\mathrm{GA}_{3} 5 \mathrm{mg} / \mathrm{L}\end{array}$ & BAP $1 \mathrm{mg} / \mathrm{L}$ & $3 \%$ sucrose & \\
\hline $\begin{array}{l}\text { Embryogenesis Induction Medium } \\
\text { MIE }\end{array}$ & $\begin{array}{l}\text { MS full } \\
\text { strength }\end{array}$ & & $\begin{array}{l}\text { BAP } 10 \\
\mathrm{mg} / \mathrm{L}\end{array}$ & $6 \%$ glucose & $\begin{array}{c}\text { Adenina } 40 \mathrm{mg} / \mathrm{L} \\
\text { Putrescine } 161.1 \mathrm{mg} / \mathrm{L}\end{array}$ \\
\hline $\begin{array}{l}\text { Embryos Germination Medium } \\
\text { (EGM) }\end{array}$ & $\begin{array}{l}\text { MS full } \\
\text { strength }\end{array}$ & $\begin{array}{c}\mathrm{GA}_{3} \\
0.01 \mathrm{mg} / \mathrm{L}\end{array}$ & $\begin{array}{l}\text { BAP } 0.2 \\
\mathrm{mg} / \mathrm{l}\end{array}$ & $3 \%$ sucrose & Putrescine $161.1 \mathrm{mg} / \mathrm{L}$ \\
\hline $\begin{array}{c}\text { Secondary Embryogenesis Medium } \\
\text { (SEM) }\end{array}$ & $\begin{array}{l}\text { MS full } \\
\text { strength }\end{array}$ & & BAP $1 \mathrm{mg} / \mathrm{L}$ & $2 \%$ sucrose & $\begin{array}{l}\text { Casein hydrolyzed } 200 \text { mg/L } \\
\text { Putrescine } 161.1 \mathrm{mg} / \mathrm{L} \text { Adenine } \\
40 \mathrm{mg} / \mathrm{L}\end{array}$ \\
\hline
\end{tabular}

species are still limited to the genotype. The aim of this work was to develop an efficient and reproducible somatic embryogenesis protocol from cotyledons of Melia azedarach L. This methodology will allow obtaining a great number of plants applied to reforestation projects, cryoconservation, production of synthetic seeds and genetic transformation for improvement programs of this species.

\section{MATERIALS AND METHODS}

\section{Plant material and culture conditions}

Mature fruits of Melia azedarach were collected from 20 to 30 years old trees with desirable forestry characteristics (fast growing, straight stem, healthy), growing in a seed orchard in Guanajuato, México. The seeds were excised by removing fruit coats in a mechanical way and they were used as a source of explants. Seeds were surface-sterilized in $70 \%(\mathrm{v} / \mathrm{v})$ ethanol for $3 \mathrm{~min}$, then $20 \%(\mathrm{v} / \mathrm{v})$ Clorox $(6 \%$ $\mathrm{NaOCl}$ ) solution with Tween 20 (4 drops per $100 \mathrm{ml}$ solution) for $30 \mathrm{~min}$, and rinsed three times in sterile distilled water. About 350 seeds were used in each experiment. The seeds were germinated directly on different induction media. Ten seeds were plated per Petri dish $(100 \times 10 \mathrm{~mm})$ containing $20 \mathrm{ml}$ of culture medium. Each treatment consisted of 35 replicates and each experiment was repeated three times. All the cultures were incubated under a $16 \mathrm{hrs}$ photoperiod $\left(50 \mu\right.$ moles $\mathrm{x} \mathrm{m}^{2} \mathrm{x}$ sec provided by cool-white and day light Sylvania fluorescent lamps) at $27^{\circ} \mathrm{C}$.

\section{Culture media and conditions}

The culture media used were Murashige and Skoog's (1962) vitamins, macro and micronutrients at full or half strength concentration. All the media were gelled with $2.5 \mathrm{~g} / 1$ Gelrite $^{\mathrm{TM}}$ or $7.0 \mathrm{~g} / \mathrm{L}$ Phytoagar Gibco ${ }^{\mathrm{BRL}}$ and supplemented with a broad range of PGR and other additives (hydrolyzed casein, vitamins, sucrose, glucose) to induce callogenesis. Citokinins (BAP and Kinetin), auxins (2,4-D, NAA, IAA, IBA) and giberellic acid $\left(\mathrm{GA}_{3}\right)$ were used in a range of 0.01 to $10 \mathrm{mg} / \mathrm{L}$ as $\mathrm{PGR}$. Adenine free base (Sigma) was dissolved and added (40-80 mg/L). Putrescine was used at 1 $\mathrm{mM}$ as a source of polyamines. The $\mathrm{pH}$ of all media was adjusted to 5.8-6.0 before autoclaving. All media were sterilized by autoclaving for $17 \mathrm{~min}$ at $121^{\circ} \mathrm{C}$ at $15 \mathrm{lbs}$. pressure. All cultures were incubated under a 16-h photoperiod $\left(50 \mathrm{~mm} \mathrm{x} \mathrm{m}^{2} \mathrm{x} \mathrm{sec}\right.$, provided by cool-white and day light Sylvania fluorescent lamps) at $27^{\circ} \mathrm{C}$.

\section{Embryogenesis induction and plant regeneration}

The freshly formed embryogenic callus from cotyledons was sub cultured on Embryogenesis Induction Medium MIE. Mature somatic embryos were sub cultured to obtain synchronous and normal germination. Three different media were used for this: 1) MS salts and vitamin free hormone medium (MS); 2) Embryo Germination Medium (EGM). 3) Secondary Embryogenesis Medium (SEM). All the media are shown in Table 1. Plants were sub cultured to $500 \mathrm{ml}$ vessels with MS half strength hormone-free medium supplemented with $1 \%$ sucrose, to promote their elongation. Then they were placed in pots with Peat Most (Sunshine). Plants were grown in a Plant Tissue Culture Chamber Model CU-36L (Percival Scientific) at $25^{\circ} \mathrm{C}$ and continuous light provided by cold-white General Electric fluorescent lamps. The plants were covered with nylon and spread once with fungicide solution (Benlate, $1 \mathrm{mg} / 100$ $\mathrm{ml})$. After two weeks, they were transferred to pots with soil under greenhouse conditions. One month later, they were transplanted to field conditions. 
Table 2. Diagrammatic representation of the optimized somatic embryogenic pathway for Melia azedarach $L$.
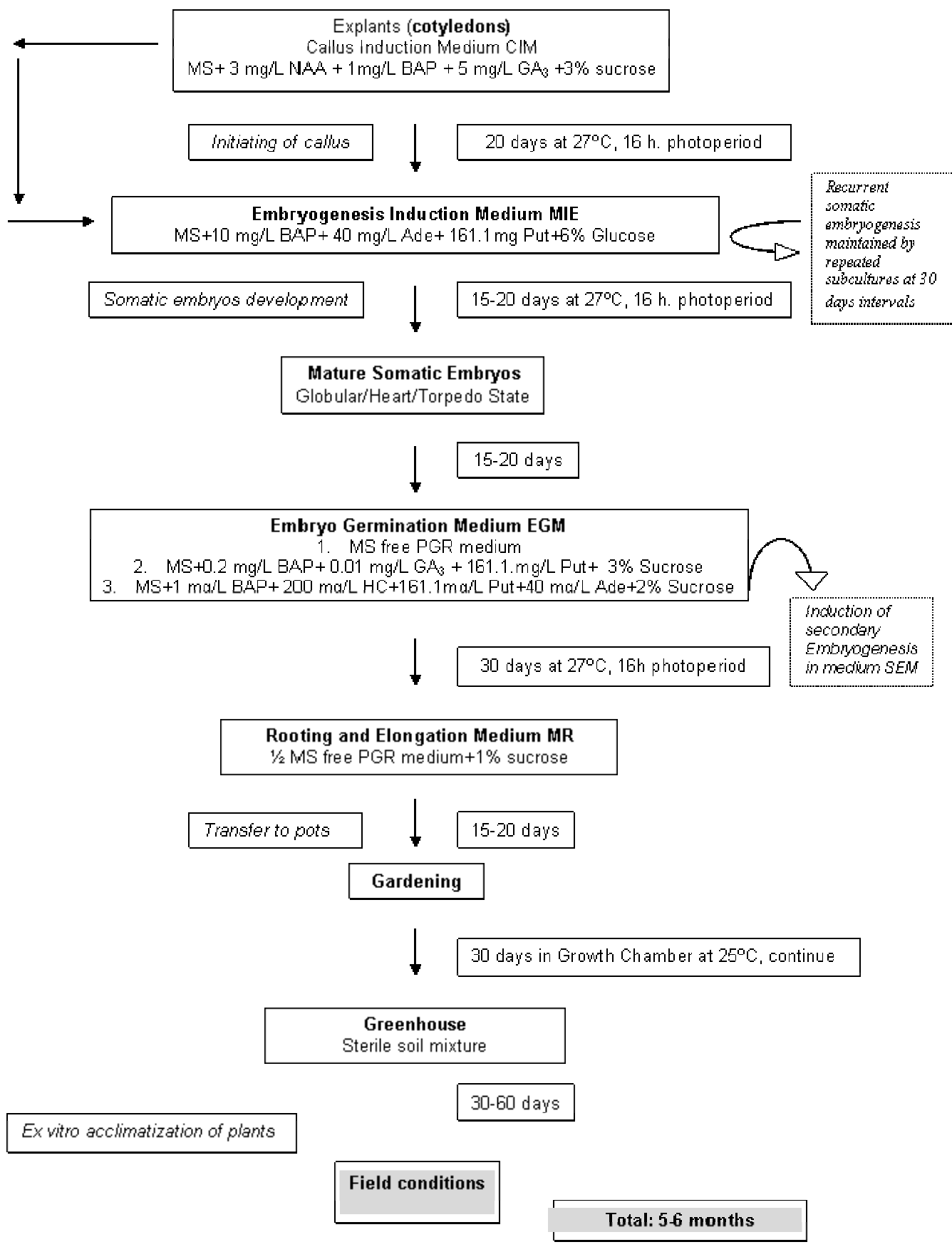

\section{RESULTS AND DISCUSSION}

\section{Induction and propagation of embryogenic calli}

The pathway of somatic embryogenesis obtained was indirect because it needed to pass through a callus phase. Seedling tissues started dedifferentiation after seven days of culture. After 20 days in culture, embryogenic calli were formed from cotyledons in $93 \%$ of the explants on CIM medium. They were then sub cultured to IEM medium for somatic embryo development. Embryogenic callus were heterogeneous, light brown to green in colour, friable and with high number of somatic embryos in different states, easy to separate from callus surface (Figure 1a). As can be observed, the efficiency of embryogenic calli formation per initial explant was very high. The reproducibility was always high. An average of 447 embryos per gram of callus fresh weight was obtained. All the different stages of 
somatic embryogenesis were easily observed after 15 to 20 days in EIM medium (from globular to mature somatic embryos) as can be seen in Figure 1b. The standard process for somatic embryogenesis consists in callus formation in media containing auxins and afterwards subculture to hormone free medium (Reinert, 1967). The presence of an auxin is usually required in the medium in order to maintain the growth of subcultures (Halperin, 1995). Moreover, the type and concentration of auxin employed are critical for the induction and formation of somatic embryos. Auxin 2, 4-D has been the most efficient PGR for the induction of somatic embryogenesis (Merkle, 1995). However, in some cases this auxin was not necessary in the development of somatic embryos (Smith and Krikorian, 1990). In our work, it is clear that although 2,4-D (data not show) had a positive effect on callus formation, it had not effect on induction of morphogenic callus. It is possible that the somatic embryogenesis in Melia is an example of regeneration from pre-embryogenic determined cells (Evans et al. 1981), and it does not depend on 2, 4-D requirement (Litz et al. 1987). On the other hand, we found that cytokinin concentration was very important for somatic embryos development in
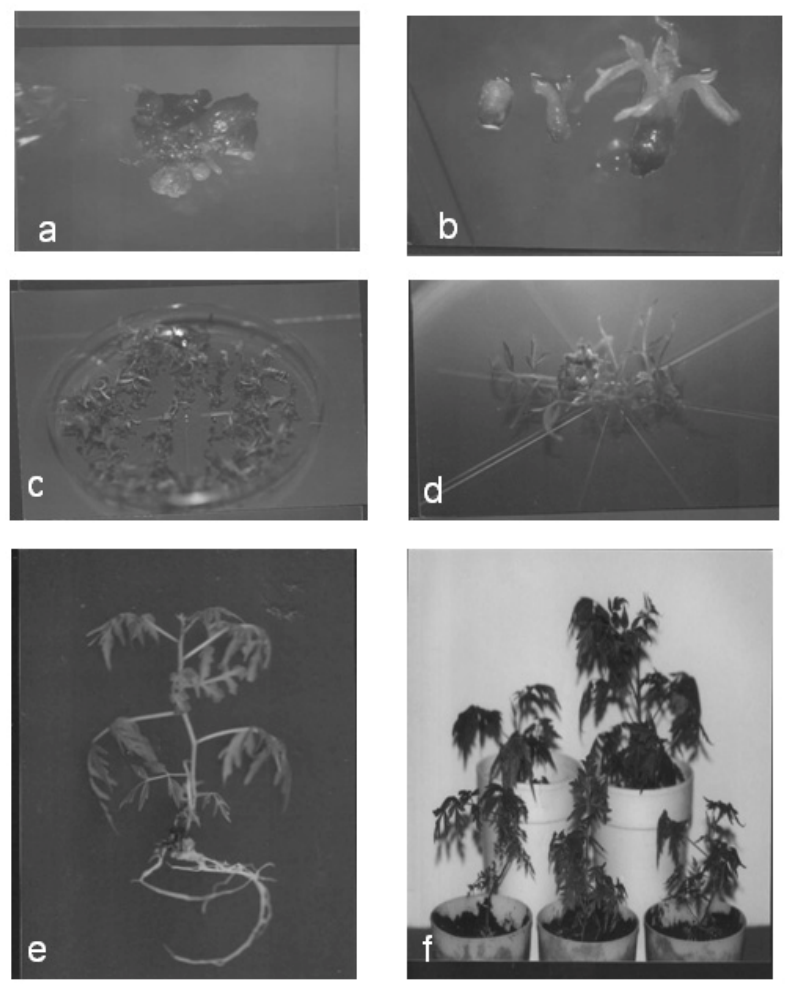

Figure 1. Somatic embryogenesis process in Melia azedarach (CINVESTAV, 1998). Arrows signaling somatic embryos

(a) Indirect somatic embryogenesis from callus.

(b) Different states of somatic embryos.

(c) Somatic embryos germination.

(d) Somatic embryos conversion.

(e) Whole plant.

(f) Acclimatization of whole plants. this species. In our work, induction of calli occurred with ANA/BAP and it seemed that it is important to have a high concentration of BAP $(10 \mathrm{mg} / \mathrm{L})$ plus adenine for somatic embryo differentiation. The cytokininzeatin was reported by Fujimura and Komamine (1978) to promote embryogenesis in a narrow concentration range, and Nomura and Komamine (1995) mentioned that other synthetic cytokinins such as BA and kinetin did not show promotive effects. Effect of induction of cytokinins over the somatic embryogenesis process was reported also by Kavathekar et al. (1978), Jha et al. (1981) and Desai et al. (1986). Shrikhande et al. (1993) obtained the best response with BAP $(1 \mathrm{mg} / \mathrm{l})$ in neem. BAP was the most suitable cytokinin for Melia because kinetin induced only noorganogenic calli (data not show, preliminary experiments). This is similar to results obtained by Nirmalakumari et al. (1993) and Drew (1996) in neem (Azadirachta indica Juss.) where kinetin alone in the media caused only no morphogenic callus induction.

\section{Somatic embryos germination and conversion}

Somatic embryos were green in colour and they had to be separated from callus and sub cultured to fresh medium, or necrosis occurred. The right stage of somatic embryogenesis to subculture the somatic embryos were torpedo and cotyledon stage. For embryo germination, the transfer to a free hormone medium or with low concentration of $\mathrm{GA}_{3}(0.01 \mathrm{mg} / \mathrm{l})$ and BAP $(0.1 \mathrm{mg} / \mathrm{L})$ without auxin, was effective (Figure 1c). The germination occurred in each of the three different culture media: 1) Free-hormone MS complete or half strength medium with adenine in different concentrations; 2) EGM medium; 3) SEM medium. Complete and normal plants were produced in 1 month (Figure 1d). One hundred per cent of somatic embryos conversion to plants phenotypically normal was achieved after 1 month of culture in light conditions (Figure 1e). The plants were subcultured to MS medium without PGR. A process of secondary somatic embryogenesis was observed in somatic embryos or in the stem base of the new plantlets in SEM medium. This process could have importance in the establishment of a genetic transformation system, which permits a high frequency of regeneration (Fernández and Menédez, 2003). With respect to the efficiency of the system and in reference to the tree "neem", Nirmalakumari et al. (1993) obtained 8-10 plantlets per explant through direct somatic embryogenesis during 4-5 months; Shrikhande et al. (1993), and Murthy and Saxena (1998) obtained somatic embryogenesis with $60-70 \%$ of conversion of embryo to plant and $80 \%$ surviving in field condition, and Joshi and Thengane (1996) obtained somatic embryos from cotyledons recovering 2025 embryos per explants with $2-5 \%$ of germination in $\mathrm{MS} / 2$ medium. Our results show remarkably more efficiency compared to other reports.

\section{Hardening-off}


When whole plants were transferred to pots, $100 \%$ of surviving plants were obtained in chamber culture, greenhouse and field conditions (Figure 1f). Plants were phenotypically normal and roots were vigorous and normal too. Plants with fungi contamination did not present problems when they were sub-cultured to soil. It is probably that the antifungal active principles of this species (Carpinella et al. 1999) inhibited fungal growth.

\section{Addition of putrescine and adenine}

Putrescine. Polyamines are present in all living cells and they are required for growth and development in many biological systems (Rajam and Galston, 1985; El Hadrami and D'auzoc, 1992). Malmberg et al. (1998) observed interactions between polyamines and either ethylene and cytokinin and they suggested that the biological functions and associated mechanisms of action of polyamines are not understood yet. In this work, somatic embryos in EGM medium without putrescine developed abnormal cotyledons (data not shown) and the addition of putrescine in this culture medium avoided this problem. On the other hand, we observed secondary somatic embryogenic process in somatic embryos and plantlets derived from them. In Melia, putrescine increases secondary embryogenesis in SEM medium. These results are not supported in the literature because in general exogenous application of polyamines does not affect somatic embryogenesis (Feirer et al. 1985; Litz et al. 1987), although the increased biosynthesis of polyamine may be accompanied by embryogenesis (Montague et al. 1978; Minocha and Minocha, 1985).

Adenine. High levels of BAP in combination with adenine promote somatic embryogenesis in this species. In medium without adenine we not observed embryos formation. It is possible that adenine allows somatic embryos development. The adenine has been shown precursor of the purine moiety of cytokinins and it producing ATP too (Chen et al. 1985). It is possible that adenine is incorporated as a precursor in the biosynthesis of cytokinins in this tissue culture system.

\section{CONCLUDING REMARKS}

The developed protocol established the potential to produce plantlets from cotyledon explants through somatic embryogenesis. The general procedure and time frame for plant regeneration of chinaberry developed from embryogenesis is presented in Table 2. This is a simple, rapid, inexpensive and efficient plant regeneration system in terms of recovery of large numbers of plants for this species. From the mature seed culture to plant regeneration, a maximum of six months was required. Somatic embryogenesis with high percent of conversion of embryos to plants will allow adjusting the methodology to produce synthetic seeds and its use in vitro selection for abiotic stress resistant. Secondary embryogenesis process is fundamental from the point of view of genetic transformation, because the cyclic formation of somatic embryos is important when genetic transformation of plants with biolistics or Agrobacterium system can be applied. The success of utilizing somatic embryogenesis as a component of a genetic transformation system or for clonal propagation depends largely on the efficiency of the in vitro system (Li and Wolyn, 1996). This protocol of induction of somatic embryogenesis and plant production could be relevant for biochemical, biological and genetics studies. This is the first report of somatic embryogenesis in Melia azedarach L. It also offers itself as a highly efficient method for mass clonal propagation and conservation of Melia azedarach.

\section{REFERENCES}

AHMAD, Z.; ZAIDI, N. and SHAH, F. Micropropagation of Melia azedarach from mature tissue. Pakistan Journal of Botany, 1990, vol. 22, no. 2, p. 172-178.

CARPINELLA, M.; HERRERO, G.; ALONSO, R. and PALACIOS, S. Actividad antifungica de extractos del fruto del paraiso (Melia azederach L.). Fitoterapia, 1999, vol. 70, p. 296-298.

CHEN, C.H.; ERTL, J.; LEISNER, S. and CHENG, C.H. Localization of citokynin biosynthetic sites in pea plants and carrot roots. Plant Physiology, 1985, vol. 78, no. 3, p. 510-513.

DESAI, H.; BHATT, P. and MEHTA, A. Plant regeneration of Sapindustrifoliatus L. (Soapnut) through somatic embryogenesis. Plant Cell Reports, 1986, vol. 3, no. 3, p. 190-191.

DOMECQ, C. In vitro culture of shoot tips of Melia azedarach var. gigantea. Phyton, 1988, vol. 48, no. 1-2, p. $33-42$.

DREW, R. Clonal propagation of neem by tissue culture. In: SINGH, R.P.; CHARI, M.S.; RAHEJA, A.K. and KRAUS, W. eds. Neem and environment, vol. 2. Science Publishers, Inc., Lebanon, New Hampshire. 1996, p. 9991005.

EL HADRAMI, I. and D'AUZAC, J. Effects of polyamine biosynthetic inhibitors on somatic embryogenesis and cellular polyamines in Heveabrasiliensis. Journal of Plant Physiology, 1992, vol. 140, p. 33-36.

EVANS, D.A.; SHARP, W. and FLICK, C. Growth and behaviour of cell cultures. In: THORPE, Trevor A. ed. Plant Tissue Culture- Methods and Application in Agriculture. Orlando, Florida, USA. Academic Press, 1981, p. $45-113$.

FEIRER, R.; WANN, S. and EINSPAHR, D. The effect of spermidine synthesis inhibitors on in vitro plant development. Plant Growth Regulators, 1985, vol. 3, no. 34, p. 319-327. 
FERNÁNDEZ, R. and MENÉDEZ, A. Transient gene expression in secondary somatic embryos from coffee tissues electroporated with the genes gus and bar. Electronic Journal of Biotechnology [online]. 15 April 2003, vol. 6, no. 1 [27 October 2005]. Available from Internet:

http://www.ejbiotechnology.info/content/vol6/issue1/full/6/ index.html.

FUJIMURA, T. and KOMAMINE, A. Mode of action 2,4D sndzeatin on somatic embryogenesis in a carrot cell suspension cultures of carrot. Zeitschrift fur Pflanzaphysiologie, 1978, vol. 86, p. 55.

HALPERIN, W. In vitro embryogenesis: some historical issues and unresolved problems. In: THORPE, Trevor A. ed. In vitro embryogenesis in plants. Current plant science and biotechnology in agriculture, vol. 20.Kluwer Academic Publishers, Dordrecht, Netherlands. 1995, p. 1-15.

JHA, T.; ROY, S. and MITRA, C. A brief review of in vitro studies on umbelliferous spice plants. In: RAO, A.N. ed. Proceedings COSTED Symposium on tissue culture of economically important plants. $\left(28^{\text {th }}-31^{\text {st }}\right.$ April, 1981, Singapur, Malaysia). 1981. p. 94-97.

JOSHI, M. and THENGANE, S. Potential application of in vitro methods for propagation of neem (Azadirachta indica A. Juss). In: CHARI, M.S., RAHEJA, A.K. and KRAUS, W. Neem and Environment, vol. 2, 1996, R.P Singh, Science Publishers, Inc., Lebanon, New Hampshire 03766 USA, p. 967-973.

KAVATHEKAR, A.; GANAPATHI, P. and JOHRI, B. In vitro response of embryoids of Eschscholzia. Biologia Plantarum, 1978, vol. 20, p. 98-106.

LI, B. and WOLYN, D. Temperature and genotype affect aspargus somatic embryogenesis. In vitro Cell and Developed Biology-Plant, 1996, vol. 32, no. 3, p. 136-139.

LITZ, R. and SCHAFFER, B. Polyamines in adventitious and somatic embryogenesis in mango (Mangifera indica L.). Journal of Plant Physiology, 1987, vol. 128, p. 251258.

MALMBERG, R.; WATSON, M.; GALLOWAY, G. and YU, W. Molecular genetic analyses of plant polyamines. Critical Review in Plant Science, 1998, vol. 17, no. 2, p. 199-224.

MERKLE, S.A. and DEAN, J. Forest tree biotechnology. Current Opinion in Biotechnology, 2000, vol. 11, no. 3, p. 298-302.

MERKLE, S.A. Strategies for dealing with limitations of somatic embryogenesis in hardwood trees. Plant Tissue Culture and Biotechnology, 1995, vol. 1, no. 3, p. 112-121.
MERKLE, S.; PARROTT, W. and WILLIAMS, E. Applications of somatic embryogenesis and embryo cloning. In: BHOJWANI, S. ed. Plant tissue culture: applications and limitations. Elsevier, Amsterdam, Netherlands. 1990, p. 67-101.

MINOCHA, S.C. and MINOCHA, R. Role of polyamines in somatic embryogenesis. In: Bajaj, Y.P.S. eds. Biotechnology in Agriculture and Forestry, vol 30, Somatic Embryogenesis and Synthetic Seed I. Heidelberg, Germany: Springer-Verlag; 1995, p. 53-70.

MONTAGUE, M.; KOPPENBRINK, J. and JAWORSKI, E. Polyamine metabolism in embryogenic cells of Daucuscarota. I. Changes in intracellular content and rates of synthesis. Plant Physiology, 1978, vol. 62, no. 3, p. 430433.

MURASHIGE, T. and SKOOG, F. A revised medium for rapid growth and bioassays with tobacco tissue culture. Phisiologia Plantarum, 1962, vol. 15, p. 473.

MURTHY, B. and SAXENA, P. Somatic embryogenesis and plant regeneration of neem (Azadirachta indica A. Juss). Plant Cell Reports, 1998, vol. 17, no. 6-7, p. 469475 .

NIRMALAKUMARI, A.; RAMASWAMY, N. and SREE RANGASWAMY, S. Tissue culture studies in neem (Azadirachta indica A. Juss). In: Proceedings of World Neem Conference. $\left(24^{\text {th }}-28^{\text {th }}\right.$ February, 1993, Bangalore, India). 1993. p. 981-992.

NOMURA, K. and KOMAMINE, A. Physiological and biological aspects of somatic embryogenesis.In: Thorpe, T.A, ed. In Vitro Embryogenesis in Plants. Kluwer Academic Publishers, Dordrecht, The Netherlands, 1995. p. 249-266.

OLMOS, S.E.; LAVIA, G.; DI RENZO, M.; MROGINSKI, L. and ECHENIQUE, V. Genetic analysis of variation in micropropagated plants of Melia azedarach 1. In Vitro Cellular and Development Biology - Plant, December 2002, vol. 38 , no. 6, p. 617-622.

PARK, Y.S. Implementation of conifer somatic embryogenesis in clonal forestry: technical requirements and deployment considerations. Annals of Forestry Science, 2002, vol. 59, p. 651-656.

PRASSAD, M.; RANGANATHA, A.; SUJATHA, M.; MUKTA, D.; RAMACHANDRAM, M. and NAGRAJ, G. Investigations on neem and Melia for sustainable production. In: Proceedings of World Neem Conference. $\left(24^{\text {th }}-28^{\text {th }}\right.$ February, 1993, Bangalore, India). 1993. p. 993998.

RAJAM, M. and GALSTON, A. The effects of some polyamine biosynthetic inhibitors on growth and 


\section{Sharry, S. et al.}

morphology of phytopathogenic fungi. Plant Cell Physiology, 1985, vol. 26, no. 4, p. 683-692.

REINERT, J. Some aspects of embryogenesis in somatic cells of Daucuscarota. Phytomorphology, 1967, vol. 17, no. $1-6$, p. $510-518$.

SAYMAIYA, R.K. and SHUKLA, K.C. Biodiversity conservation through agro forestry system. Advances in Plant Sciences, 1998, vol. 11, no. 2, p. 111-115.

SCHMIDT, G.; REMBOL, H.; AHMED, A. and BREUER, M. Effect of Melia azedarach fruit extract on juvenile hormone titer and protein content in the hemolynph of two species of noctuidlepidopteran larvae. Phytoparasitica, 1998, vol. 26, no. 4, p. 283-291.

SHARRY, S. and ABEDINI, W. Selección de callos organogénicos tolerantes a baja temperatura y regeneración de plantas de Melia azedarach L. Revista Fitotecnia Mexicana, 2001, vol. 24, no. 1, p. 95-102.

SHRIKHANDE, M.; THENGANE, S. and MASCARENHAS, A. Somatic embryogenesis and plantlet regeneration in neem Azadirachta indica A. Juss. In VitroCellular and Developmental Biology-Plant, 1993, vol. 29, no. 19 , p. 38-42.

SMITH, D.L. and KRIKORIAN, A. Somatic embryogenesis of carrot in hormone-free medium: external $\mathrm{pH}$ control of morphogenesis. American Journal of Botany, 1990, vol. 77, no. 12, p. 1634.

SUTTON, B. Commercial delivery of genetic improvement to conifer plantation using somatic embryogenesis. Annals of Forestry Science, 2002, vol. 59, p. 657-661.

THAKUR, R.; RAO, P. and BAPAT, V. In vitro plant regeneration in Melia azedarach. L. Plant Cell Reports, 1998, vol. 18, vol. 1-2, p. 127-131.

TZFIRA, T.; ZUKER, A. and ALTMAN, A. Forest-tree biotechnology: genetic transformation and its application to future forests. Trends in Biotechnology, 1998, vol. 16, no. 19, p. 439-446.

VILA, S.; GONZALES, A.; REY, H. and MROGINSKI, L. In vitro plant regeneration of Melia azedarach L.: Shoot organogenesis from leaf explant. Biologia Plantarum, 2003-2004, vol. 47, no. 1, p. 13-19.

VILA, S.; GONZALEZ, A.; REY, H. and MROGINSKI, L. Somatic embryogenesis and plant regeneration from immature zygotic embryos of Melia azedarach (Meliaceae). In Vitro Cellular and Development Biology Plant, May 2003, vol. 39, no. 3, p. 283-287.

WANG, J.W.; WANG, Q.K. and CHIU, S. Insecticidal compounds in Meliaceae. Acta Entomologica Sinica, 1994, vol. 37, no. 1, p. 20-24. 